\title{
PELATIHAN KEWIRAUSAHAAN BIDANG PARIWISATA DI DESA CADAS NGAMPAR SENTUL
}

\author{
Imam Ardiansyah ${ }^{1}$, Sofiani ${ }^{2 *}$, Yudhiet Fajar Dewantara ${ }^{3}$, Stephanie Rosanto ${ }^{4}$, \\ Vivian Octariana ${ }^{5}$, Muhammad Sutiyadi ${ }^{6}$ \\ ${ }^{1-6}$ Hospitaliti dan Pariwisata - Universitas Bunda Mulia \\ Email Korespondensi: sofiani@bundamulia.ac.id
}

Disubmit: 16 Juli 2021

Diterima: 04 Desember 2021
DOI: https://doi.org/10.33024/jkpm.v1i1.4687

Diterbitkan: 01 Januari 2022

\section{ABSTRAK}

Penerapan kebijakan Pembatasan Sosial Berskala Besar (PSBB) oleh pemerintah Indonesia berdampak besar terhadap penurunan kegiatan ekonomi di masyarakat. Hal tersebut memberikan pengaruh kepada sejumlah pengusaha terpaksa membuat keputusan dengan menutup usahanya dan sebagian karyawannya dirumahkan atau melakukan pemutusan hubungan kerja karena beban operasional yang tetap berjalan, seperti biaya sewa tempat, listrik, maupun gaji karyawan sementara tidak ada pemasukan. Bagi pengusaha yang memiliki modal yang besar, kemungkinan masih bisa bertahan untuk beberapa waktu ke depan. Namun lain halnya bila pengusaha yang memiliki modal yang relatif kecil atau pas-pasan. Tentu menjadi pekerjaan rumah yang tidak mudah untuk bertahan. UMKM merupakan salah satu sector yang terimbas dari adanya Pemabatasan tersebut. Oleh karena itu, Universitas Bunda Mulia melalui program Pengabdian kepada Masyarakat (PKM) ini, membantu para penggiat UMKM di Desa Cadas Ngampar untuk dapat bangkit dan berinovasi dalam menjalankan usahanya. Tujuan dari kegiatan pengabdian kepada masyarakat ini adalah untuk melatih kemampuan berwirausaha masyarakat di desa cadas ngampar. Beberapa paparan materi yang disampaikan dalam PKM ini diharapkan dapat meningkatkan kualitas UMKM warga lokal dan meningkatkan lagi perekonomian di Desa Cadas Ngampar. Setelah melakukan penyuluhan dengan pemaparan materi dari masingmasing dosen maka hasil yang di dapatkan berdasarkan intensitas tanya jawab yang muncul, kegiatan pengabdian ini adalah adanya peningkatan pengetahuan dan pemahaman serta keterampilan peserta dalam kewirausahaan, dapat mengetahui manfaat-manfaat dari materi yang disampaikan, dan adanya tambahan motivasi dalam berwirausaha.

Kata Kunci: Kewirausahaan, Pemasaran, Higiene dan Sanitasi

\begin{abstract}
The implementation of the Large-Scale Social Restriction (PSBB) policy by the Indonesian government has had a major impact on the decline in economic activity in the community. This has affected a number of entrepreneurs who were forced to make decisions by closing their businesses and some of their employees being laid off or terminating their employment due to ongoing operational expenses, such as the cost of renting a place, electricity, or employee salary while there is no income. For entrepreneurs who have large capital, chances are they can survive for some time to come. However, it is different if the entrepreneur has a relatively small or mediocre capital. Of course, being a homework that is not easy to survive. MSMEs are one of the
\end{abstract}


sectors affected by these restrictions. Therefore, Universitas Bunda Mulia through this Community Service (PKM) program, helps MSME activists in Cadas Ngampar Village to be able to rise and innovate in running their business. The purpose of this community service activity is to train community entrepreneurship skills in the village of rock ngampar. Some of the material presentations presented in this PKM are expected to improve the quality of local MSMEs and improve the economy in Cadas Ngampar Village. After conducting counseling with material presentation from each lecturer, the results obtained were based on the intensity of the questions and answers that emerged, this service activity was an increase in the knowledge and understanding and skills of participants in entrepreneurship, being able to find out the benefits of the material presented, and additional motivation in entrepreneurship.

Keywords: Entrepreneurship, Marketing, Hygiene and Sanitation

\section{PENDAHULUAN}

Penerapan kebijakan Pembatasan Sosial Berskala Besar (PSBB) oleh pemerintah berdampak besar terhadap penurunan kegiatan ekonomi di masyarakat (Kemenko PMK, 2020). Mereka cenderung menahan diri untuk melakukan konsumsi yang berlebihan dan memilih untuk memprioritaskan pemenuhan kebutuhan pokok. Efek dari hal itu, sejumlah pengusaha membuat keputusan dengan menutup usahanya dan sebagian karyawannya dirumahkan atau melakukan pemutusan hubungan kerja karena beban operasional yang tetap berjalan seperti biaya sewa tempat, listrik, maupun gaji karyawan sementara tidak ada pemasukan. Bagi pengusaha yang memiliki modal yang besar mereka mungkin masih bisa bertahan untuk beberapa waktu kedepan namun lain halnya bila pengusaha yang memiliki modal yang relatif kecil atau pas-pasan tentu menjadi pekerjaan rumah yang tidak mudah untuk bertahan.

Menurut Fahmi (2013) Kewirausahaan adalah suatu ilmu yang mengkaji tentang pengembangan dan pembangunan semangat kreativitas serta berani menanggung risiko terhadap pekerjaan yang dilakukan demi mewujudkan hasil karya tersebut. Kewirausahaan juga sebagai proses menciptakan sesuatu yang baru dan memiliki nilai dengan mengorbankan waktu dan tenaga, melakukan pengambilan risiko finansial, fisik, mapun sosial, serta menerima imbalan moneter dan kepuasan serta kebebasan pribadi (Slamet et al., 2014). Desa Cadas Ngampar Sentul adalah salah satu desa yang memiliki potensi kewirausahaan yang baik untuk di kembangkan karena areanya yang dekat dengan tempat wisata di daerah Sentul.

Menurut Alma (2009) terdapat beberapa keuntungan yang diterima, tetapi dibalik itu semua terdapat kerugian yang menjadi faktor penghambat dalam melakukan wirausaha. Keuntungan dari berwirausaha adalah terbukanya peluang untuk mencapai tujuan yang dihendaki sendiri, mendemonstrasikan kemampuan dan potensi secara penuh, memperoleh manfaat secara maksimal, membantu masyarakat dengan usaha-usaha konkrit, dan menjadi pemilik atau bos. Walaupun demikian, berwirausaha memiliki kerugian, yaitu memperolah pendapatan yang tidak pasti, memikul berbagai risiko secara mandiri, perlu bekerja lebih keras, waktu kerjanya cendrung panjang, dan tanggung jawabnya sangat besar (Maydiantoro, 2021). 


\section{MASALAH}

Alasan kami memilih tempat kegiatan pengabdian kepada masyarakat di Desa Cadas Ngampar adalah karena Desa Cadas Ngampar memiliki area yang dekat dengan tempat wisata di daerah Sentul. Desa ini memiliki banyak potensi dalam mengembangkan kewirausahaan yang dapat dijadikan pemasukan dan mata pencaharian untuk para warga desa.

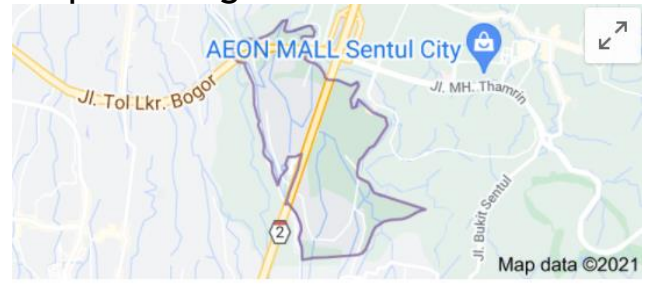

\section{Cadas Ngampar}

Desa di Jawa Barat

Cadas Ngampar adalah desa di kecamatan Sukaraja,

Bogor, Jawa Barat, Indonesia.

Provinsi: Jawa Barat

Kecamatan: Sukaraja

\section{Gambar 1.1 Peta Lokasi Kegiatan Desa Cadas Ngampar}

\section{METODE}

\section{a. Tujuan Persiapan}

Tahapan persiapan dilakukan dari tanggal 27 Maret 2021, 2 minggu sebelum kegiatan, dengan melakukan pertemuan bersama Kepala Desa Cadas Ngampar, Pak Jejen, untuk mengetahui apa saja yang dibutuhkan oleh Desa Cadas Ngampar untuk mengembangkan kegiatan kewirausahaan dari segi UMKM. Kemudian setiap perwakilan pemateri dari Universitas Bunda Mulia membuat materi yang sesuai dengan bidangnya masing-masing dan disesuaikan juga dengan kebutuhan materi untuk para pelaku usaha UMKM dan calon pelaku usaha UMKM di Desa Cadas Ngampar.

b. Tujuan Persiapan

Acara dilakuan pada hari Sabtu, 10 April 2021 di area Balai Desa Cadas Ngampar kegiatan di mulai dengan kata sambutan dari Kepala Desa Cadas Ngampar, Bapak Jejen dan Ketua Kegiatan PKM dari Universitas Bunda Mulia, Bapak Imam Ardiansyah, SST.Par, MM.Par. Dilanjutkan sambutan oleh Ketua Program Studi Hospitality dan Pariwisata Universitas Bunda Mulia oleh Ibu Supina, SST.Par., M.Par. Setelah ramah tamah, kegiatan pemaparan materi dimulai mengenai:

i. Materi Promosi UMKM oleh Imam Ardiansyah, SST.Par, MM.Par dan Supina, SST.Par., M.Par. selaku dosen Prodi Hospitality dan Pariwisata

ii. Materi Higiene dan Sanitasi Pengolahan Dapur oleh Sofiani, S.Tr.Par, M.Par dan Stephanie Rosanto, BBus., MBA. selaku dosen Prodi Hospitality dan Pariwisata

iii. Materi Pengolahan Makanan oleh Yudhiet Fajar D., S.Pd., M.Par. selaku dosen Prodi Hospitality dan Pariwisata 


\section{c. Tujuan Persiapan}

Peserta hadir sebanyak 25 orang sebagai perwakilan para pelaku usaha UMKM dari Desa Cadas Ngampar. Penganturan tempat sudah sesuai dengan rencana yang dibuat dan perlengkapan yang dilakukan untuk penyuluhan sudah tersedia serta sudah digunakan sebagaimana mestinya. Penggunaan bahasa yang digunakan sudah cukup komunikatif dalam penyampaiannya.

\section{HASIL DAN PEMBAHASAN}

Kegiatan Pengabdian ini terlaksana dengan baik dan lancar karena memang memiliki relevansi dengan kebutuhan peningkatan pemahaman dan keterampilan kepada masyarakat Desa Cadas Ngampar. Berdasarkan hasil survey sebelum pelaksanaan, peserta belum maksimal dalam beberapa aspek di penjualan di masing-masing usahanya.

Agar tujuan Pengabdian bisa efektif, maka dalam kegiatan ini dilakukan pendekatan klasikal dan individual. Pendekatan klasikal dilakukan pada saat pembekalan materi pengenalan tentang materi sedangkan pendekatan individual dilakukan pada saat role-play atau pemberian contoh dan penjawaban pertanyaan dari para peserta.

\section{a. Materi Pertama: Promosi UMKM}

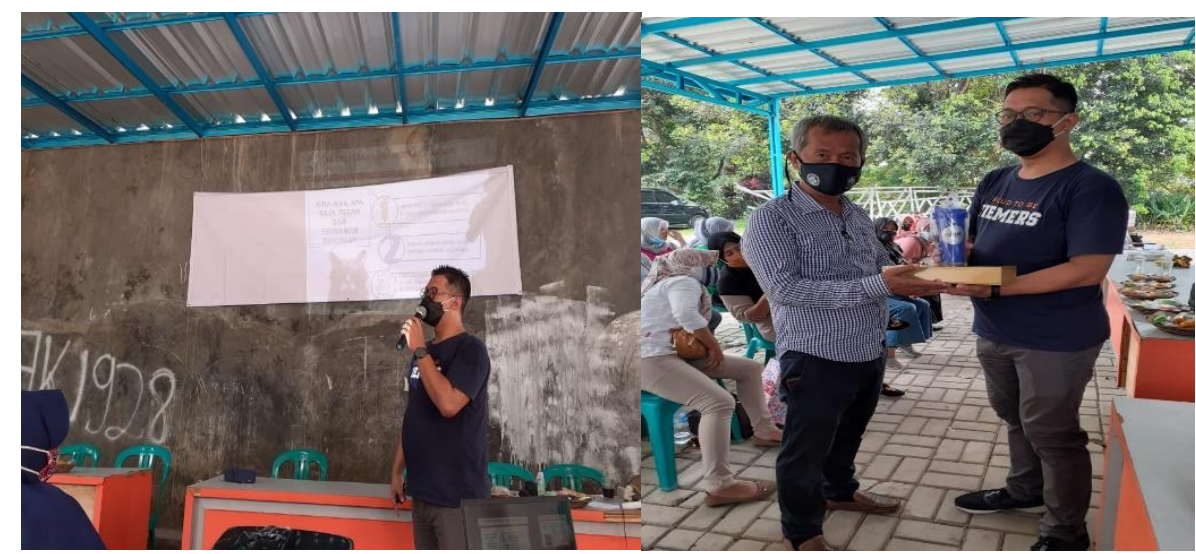

Gambar 1.2 Pemaparan Materi oleh Bapak Imam Ardiansyah, SST.Par, MM.Par

Pada sesi pemaparan promosi UMKM yang disampaikan oleh Bapak Imam berjalan dengan sangat antusias dimana materi yang disampaikan sangatlah mudah dipahami oleh para warga Desa Cadas Ngampar dan menimbulkan antusias yang sangat baik dengan banyaknya pertanyaan yang diberikan oleh para warga yang tertarik dan ingin lebih mendalami lagi materi yang di sampaikan. Hal ini juga sejalan dengan hasil kuesioner yang diberikan kepada para warga di akhir sesi.

Menurut pernyataan Kotler \& Keller (2016), definisi dari pemasaran adalah berbagai pengaturan dan proses kelembagaan untuk membuat, berkomunikasi, dan berbagi promosi yang terkait dengan pelanggan, pelanggan, mitra, dan seluruh perusahaan. Sedangkan menurut Assauri (2013), pengertian dari pemasaran adalah kegiatan yang menganalisis, merencanakan, mengimplementasikan, dan mengendalikan program yang dikembangkan untuk pembentukan, pengembangan dan pemeliharaan keuntungan perdagangan melalui tujuan pasar untuk mencapai tujuan perusahaan (perusahaan) jangka panjang. Menurut pendapat Sudaryono (2016), pemasaran itu adalah proses 
manajemen yang berupaya memaksimumkan laba bagi pemegang saham dengan jalan melalui relasi dengan pelanggan utama (valued customers) dan akan menciptakan keunggulan yang begitu kompetitif.

Kuesioner diberikan kepada para peserta pelatihan yang merupakan Bapak dan Ibu masyarakat Desa Cadas Ngampar dengan total ada 25. Hasil olah data menunjukkan respon yang positif dari para peserta terhadap kegiatan pelatihan ini. Mulai dari awal penjelasan hingga akhir, peserta terlihat menyimak dan banyak mengajukan pertanyaan disaat sesi tanya jawab. Penilaian untuk materi bervariasi dari $75 \%$ hingga $100 \%$, dengan nilai rata-rata $81 \%$. Untuk narasumber juga mendapat penilaian yang serupa, yaitu dari cakupan nilai $75 \%$ hingga $100 \%$, dengan rata-rata $83 \%$. Dengan hasil ini, dapat ditarik simpulan bahwa baik materi dan narasumber pelatihan ini sudah cukup baik dan semoga manfaat pelatihan ini dapat dirasakan seacra langsung oleh peserta.

\section{b. Materi Kedua: Higiene dan Sanitasi Pengolahan Dapur}

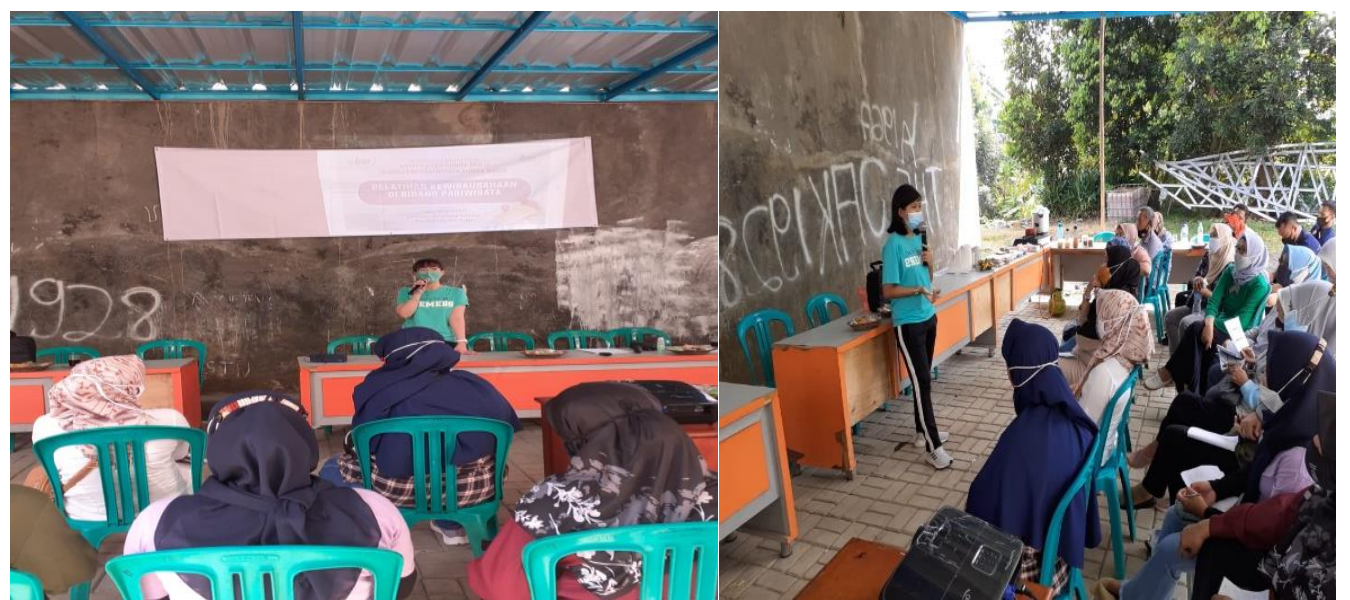

Gambar 1.3 Pemaparan Materi oleh Ibu Sofiani, S.Tr.Par, M.Par \& Ibu Stephanie Rosanto, BBus., MBA.

Menurut Brownell, higiene adalah bagaimana caranya orang memelihara dan melindungi kesehatan. Sanitasi makanan ini merupakan suatu usaha pencegahan untuk membebaskan makanan dan minuman dari segala bahaya yang dapat mengganggu, merusak kesehatan, mulai dari minuman itu sebelum diproduksi (Sihite, 2000).

Pada sesi pemaparan Higiene dan Sanitasi Pengolahan Dapur yang disampaikan oleh Ibu Sofiani dan Ibu Stephanie Rosanto berjalan dengan baik dimana hal ini merupakan salah satu materi terpenting dari kegiatan UMKM terutama di bidang kuliner. Seperti yang kita ketahui bersama, pada tahun 2020 Indonesia sedang diterpa oleh Pandemi COVID-19 yang menyebabkan terjadinya banyak pembatasan di berbagai sektor, termasuk UMKM. Hal ini juga disampaikan guna meningkatkan tingkat kesadaran pada Higiene dan Sanitasi Pengolahan Dapur para pengiat usaha UMKM di Desa Cadas Ngampar. Dengan adanya pemaparan materi mengenai Higiene dan Sanitasi, diharapkan para warga dan pengiat usaha UMKM di Desa Cadas Ngampar dapat mengaplikasikan materi dengan baik.

Dari 25 kuesioner yang diberikan kepada para peserta pelatihan pada materi kedua ini, hasil olah data menunjukkan respon yang positif dari para peserta terhadap kegiatan pelatihan ini. Mulai dari awal penjelasan hingga akhir, peserta terlihat menyimak dan banyak mengajukan pertanyaan disaat sesi tanya 
jawab. Penilaian untuk materi bervariasi dari $75 \%$ hingga $100 \%$ dengan rata-rata adalah $82 \%$. Untuk narasumber juga mendapat penilaian yang serupa yaitu dari cakupan nilai $75 \%$ hingga $100 \%$ dengan rata-rata $85 \%$. Dengan hasil ini dapat ditarik simpulan bahwa baik materi dan narasumber pelatihan ini sudah cukup baik dan semoga manfaat pelatihan juga dapat dirasakan langsung oleh peserta.

\section{c. Materi Ketiga: Pengolahan Makanan}

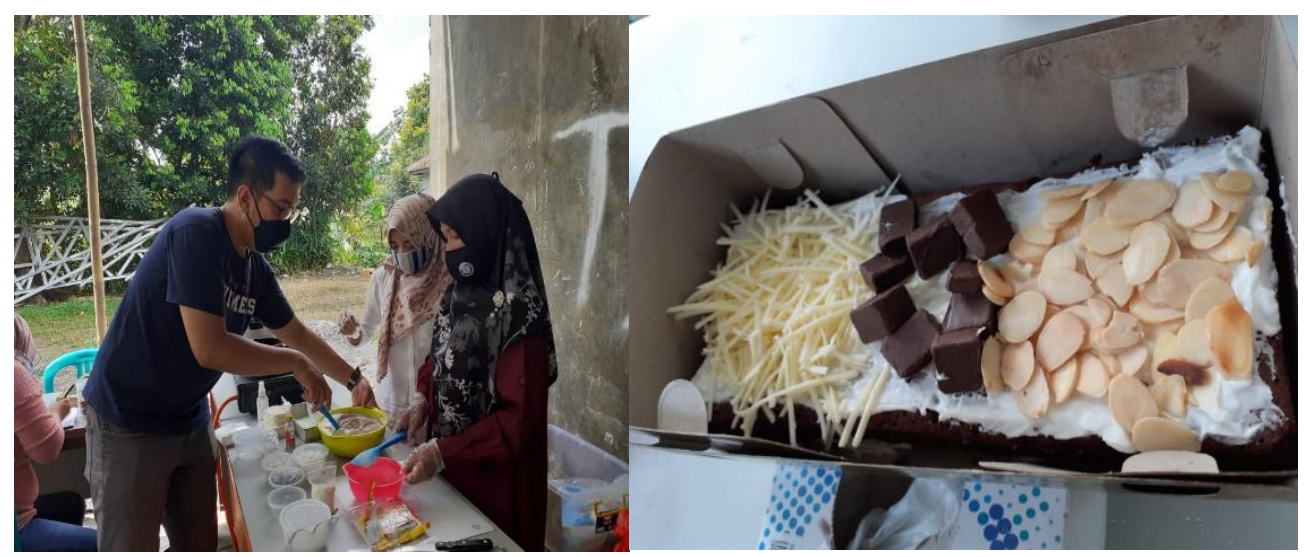

Gambar 1.4 Pemaparan Materi oleh Bapak Yudhiet Fajar D., S.Pd., M.Par.

Pada sesi pemaparan Materi Pengolahan Makanan oleh Bapak Yudhiet Fajar ini, kegiatan berlangsung sangat atraktif dimana Bapak Yudhiet Fajar lagsung mempraktikkan beberapa pembuatan kue dari bahan utama, yaitu tepung pisang. Desa Cadas Ngampar sangat kaya akan hasil alam, yaitu pisang. Pisang dapat dijadikan bahan pilihan utama untuk diproses dalam pembuatan usaha kuliner. Dengan masukan dan materi yang disampaikan, banyak warga yang antusias untuk lebih mengetahui beberapa pengolahan pisang yang sebelumnya belum diketahui. Dengan adanya input dari Bapak Yudhiet, diharapkan para warga dapat lebih mengembangkan lagi usaha kuliner yang sedang mereka jalankan dan adanya pembaharuan dari berbagai aspek, sehingga usaha yang dijalankan di bidang kuliner dapat berjalan lebih baik.

Dari hasil 25 kuesioner yang diberikan kepada para peserta pelatihan yang merupakan Bapak dan Ibu masyarakat Desa Cadas Ngampar, respon yang didapat cukup positif dari para peserta terhadap kegiatan pelatihan ini. Mulai dari awal penjelasan hingga akhir, peserta terlihat menyimak dan banyak mengajukan pertanyaan disaat sesi tanya jawab. Penilaian untuk materi bervariasi dari $75 \%$ hingga $100 \%$ dengan rata-rata adalah $81 \%$. Untuk narasumber juga mendapat penilaian yang serupa, yaitu dari cakupan nilai $75 \%$ hingga $100 \%$ dengan rata-rata 87\%. Hasil ini dapat ditarik simpulan bahwa baik materi dan narasumber pelatihan ini sudah cukup baik dan semoga manfaat pelatihan juga dapat dirasakan langsung oleh peserta. 


\section{KESIMPULAN}

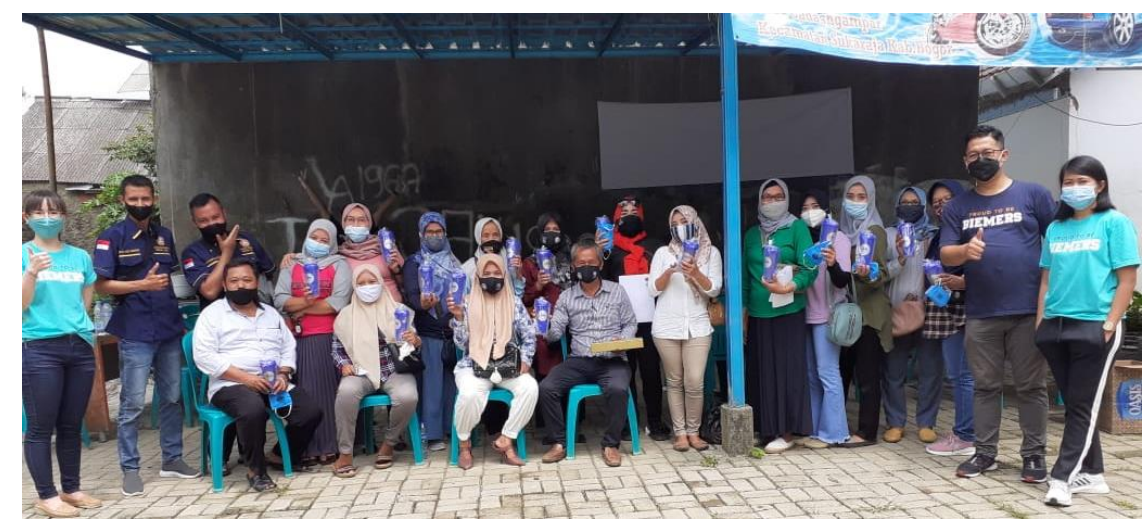

Gambar 1.5 Foto Bersama dengan Peserta PKM

Selama kegiatan berlangsung, berdasarkan intensitas tanya jawab yang muncul, kegiatan Pengabdian ini memberikan hasil sebagai berikut:

- Adanya peningkatan pengetahuan dan pemahaman serta keterampilan peserta dalam kewirausahaan

- Dapat mengetahui manfaat-manfaat dari materi yang disampaikan

- Adanya tambahan motivasi dalam berwirausaha

\section{DAFTAR PUSTAKA}

Alma, B. (2009). Manajemen pemasaran dan pemasaran jasa. Alfabeta. Assauri, S. (2013). Manajemen pemasaran. Rajawali Pers.

Fahmi, I. (2013). Pengantar manajemen keuangan. Alfabeta.

Kemenko PMK. (2020). Pembatasan Sosial Berskala Besar.

https: / /www.kemenkopmk.go.id/pembatasan-sosial-berskala-besar

Kotler, P., \& Keller, K. L. (2016). Marketing management (15th ed.). Pearson Education Inc.

Maydiantoro, A. (2021). Entrepreneurship in Higher Education Curriculla:

Evidence from Indonesia. Psychology and Education Journal, 58(3), 936949.

Sihite R. (2000). Sanitation \& hygiene: Sanitasi dan hygiene. SIC.

Slamet, F., Tunjungsari, H. K., \& le, M. (2016). Dasar-dasar kewirausahaan: Teori dan praktik (2nd ed.). Indeks.

Sudaryono. (2016). Manajemen pemasaran teori dan implementasi. Andi. 